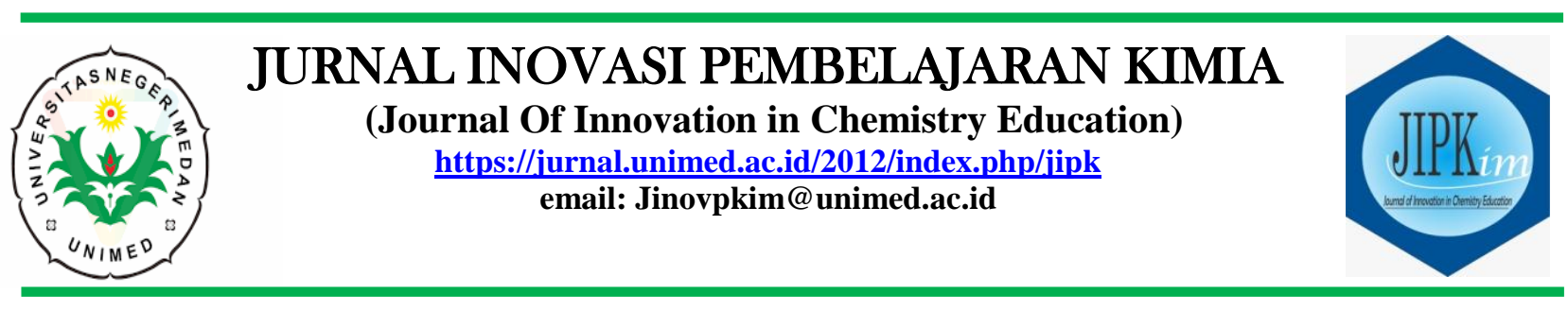

$\begin{array}{ll}\text { Masuk } & : \text { 19 September } 2021 \\ \text { Revisi } & : \text { 26 September } 2021 \\ \text { Diterima } & : \text { 16 Oktober } 2021 \\ \text { Diterbitkan } & : \text { 31 Oktober } 2021 \\ \text { Halaman } & : 116-122\end{array}$

\title{
Pengembangan E-Modul Terintegrasi Media Berbasis Adobe Flash CS6 Untuk Meningkatkan Kemampuan Pemecahan Masalah Kimia Mahasiswa
}

\author{
Freddy Tua Musa Panggabean ${ }^{1 *}$, Jamalum Purba ${ }^{1}$ \\ ${ }^{1}$ Program Studi Pendidikan Kimia, Universitas Negeri Medan, Medan \\ *Alamat Korespondensi: freddypanggabean@unimed.ac.id
}

\begin{abstract}
Supporting the implementation of an effective learning process cannot be separated from the use of teaching materials. Improving the quality of the learning process in higher education can be done with various strategies and one alternative that can be taken is the development of teaching materials. This study aims to develop an integrated e-module based on Adobe Flash CS6 media to improve students' chemistry problem solving skills on thermochemical material. The development model used refers to the ADDIE development model. Adobe Flash CS6-based integrated media e-module is designed to be accessible and downloadable by students online. The developed Adobe Flash CS6-based mediaintegrated e-module has been declared valid and proven to be effective in improving students' chemistry problem solving abilities on thermochemical materials.
\end{abstract}

Keywords: E-module, Media, Chemistry Problem Solving Ability

\section{PENDAHULUAN}

Tujuan utama dilakukannya proses pembelajaran adalam demi tercapainya keberhasilan peserta didik dalam belajar, baik pada satu mata pelajaran tertentu maupun pendidikan pada umumnya. Namun, masalah utama yang sering terjadi dalam proses pembelajaran yaitu masih rendahnya daya serap peserta didik (Siregar \& Panggabean, 2020). Hal ini disebabkan, pola pembelajaran yang sering terjadi terlalu banyak didominasi oleh guru/dosen khususnya dalam transformasi pengetahuan kepada peserta didik. Peserta didik selalu diposisikan sebagai objek, dan dianggap tidak tahu atau belum tahu apa-apa, sementara guru memposisikan dirinya sebagai sumber yang mempunyai pengetahuan.

Fakta menunjukkan bahwa dalam proses pembelajaran khususnya pembelajaran sains, peserta didik cenderung lebih menghafal konsep, teori, dan prinsip tanpa memaknai proses perolehannya. Akibatnya, peserta didik menjadi kurang terlatih untuk berpikir dan menggunakan daya nalarnya dalam memahami fenomena alam yang terjadi ataupun ketika menghadapi masalah. Pada saat diberi permasalahan baru, mereka cenderung tidak bisa menyelesaikannya, karena peserta didik/mahasiswa hanya bisa memindahkan kalimat dari buku teks ke kertas kosong. 
Tantangan besar untuk proses pendidikan ideal adalah tidak hanya mempersiapkan generasi bangsa yang mampu hidup hari ini, tetapi generasi yang dibekali dengan kemampuan hidup di masa depan. Tantangan di era global semakin kompleks dan membutuhkan penyelesaian masalah dengan pola pikir kritis dan penuh kreativitas (Noviar, 2016). Sebagian besar masalah yang dihadapi oleh lembaga pendidikan tinggi adalah bagaimana menstransfer pengetahuan dan bagaimana mengembangkan dan memastikan keterampilan praktis yang profesional dan terkini (Narmaditya et al., 2018).

Prinsip pembelajaran abad ke-21 menggunakan pendekatan pembelajaran yang berpusat pada peserta didik dimana guru maupun dosen berperan sebagai fasilitator. Selama proses pembelajaran guru maupun dosen harus mampu merancang strategi, model dan media pembelajaran yang tepat guna untuk menciptakan suasana yang mendorong dan memotovasi peserta didik untuk berpartisipasi aktif dalam kegiatan pembelajaran (Gunawan et al., 2017).

Selain penggunaan strategi atau model pembelajaran oleh guru/dosen, faktor lain yang juga menentukan keberhasilan peserta didik dalam pembelajaran adalah bahan ajar yang digunakan peserta didik sebagai sumber belajar. Penunjang terlaksananya proses pembelajaran yang efektif, tidak lepas dari penggunaan bahan ajar. Peningkatan kualitas proses pembelajaran di perguruan tinggi dapat dilakukan dengan berbagai strategi dan salah satu alternatif yang dapat ditempuh adalah pengembangan bahan ajar. Pengembangan bahan ajar dilakukan oleh seorang dosen untuk memecahkan permasalahan pembelajaran dengan memperhatikan sasaran atau mahasiswa dan juga menyesuaikan dengan kompetensi yang harus dicapai (Pratiwi et al., 2017).

Bahan ajar tidak hanya berupa buku maupun LKS yang berbasis media cetak. Bahan ajar berbasis non cetak juga dapat digunakan dalam pembelajaran misalnya dalam bentuk bahan ajar elektronik atau emodul. E-Modul adalah salah satu produk bahan ajar non cetak berbasis digital yang secara mandiri dirancang untuk dapat dipelajari oleh peserta didik (mahasiswa). EModul atau modul elektronik merupakan versi elektronik dari sebuah modul yang sudah dicetak yang dapat dibaca pada komputer dan dirancang dengan software yang diperlukan. E-modul merupakan alat atau sarana pembelajaran yang berisi materi, metode, batasan-batasan dan cara mengevaluasi yang dirancang secara sistematis dan menarik untuk mencapai kompetensi yang diharapkan sesuai dengan tingkat kompleksitasnya secara elektronik. E-modul merupakan tampilan informasi dalam format buku yang disajikan secara elektronik dengan menggunakan hard disk, disket, $\mathrm{CD}$, atau flashdisk dan dapat dibaca dengan menggunakan komputer atau alat pembaca buku elektronik (Suwasono, 2013).

E-modul yang akan dikembangakan dalam penelitian ini disusun menggunakan software atau aplikasi Kvisof Flipbook Maker. Kvisoft Flipbook Maker adalah aplikasi untuk membuat e-book, e-modul, e-paper dan $e$ magazine. Tidak hanya berupa teks, dengan aplikasi ini dapat menyisipkan gambar, grafik, suara, link dan video pada lembar kerja. Secara umum, perangkat multimedia ini dapat memasukkan file berupa pdf, gambar, video dan animasi sehingga flip book maker yang dibuat lebih menarik. Selain itu, flip book maker memiliki desain template dan fitur seperti background, tombol kontrol, navigasi bar, hyperlink dan back sound. Mahasiswa dapat membaca dengan merasakan layaknya membaca buku secara fisik karena terdapat efek animasi dimana saat berpindah halaman akan terlihat seperti membuka buku secara fisik. Hasil akhir bisa disimpan ke format html, exe, zip, screen saver dan app (Hidayatullah \& Rakhmawati, 2016).

Selain penggunaan bahan ajar sebagai sumber belajar bagi mahasiswa, faktor lain yang juga perlu dipertimbangkan seorang dosen adalah penggunaan media pembelajaran yang inovatif dan kontruktif dalam merekonstruksi pengetahuan, kemampuan dan kreativitas mahasiswa. Seorang pendidik baik guru maupun dosen 
perlu untuk merencanakan strategi, bahan ajar maupun media pembelajaran yang inovatif dan kreatif dengan memanfaatkan pembelajaran berbasis teknologi. Salah satu media yang dapat diterapkan dalam proses pembelajaran adalah media Adobe Flash CS6. Penggunaan media komputer (multimedia) dapat menjadi alternatif karena dapat mengintegrasikan animasi molekuler dan video demonstrasi (Saselah et al., 2017).

Perkembangan teknologi memicu berkembangnya e-learning yang pesat, berbagai macam perangkat lunak atau program yang telah disediakan untuk media pembelajaran yang bisa diakses setiap saat dan segala tempat. Perkembangan e-learning memicu terciptanya media pembelajarn interaktif (Busiri \& Suparji, 2015). Salah satu perangkat lunak yang sangat mendukung dalam penerapannya sebagai media pembelajaran interaktif ini adalah Adobe Flash CS6 yang memiliki seluruh elemen multimedia agar nantinya dapat digunakan secara maksimal untuk meningkatkan proses pembelajaran serta prestasi siswa (Romadhon \& Sutopo, 2017). Aplikasi Adobe Flash CS6 ini merupakan media yang mengandung unsur gerak, gambar, dan suara. Misalnya dalam bentuk media presentasi, media interaktif (Fauziah et al., 2016). Penggunaan media pembelajaran interaktif dengan Adobe Flash CS6 bisa dijadikan alternatif media pembelajaran dan mampu menjadikan pembelajaran lebih bervariasi, menarik minat belajar siswa, dan mendapatkan respon positif dari siswa (Busiri \& Suparji, 2015), diharapkan mahasiswa dapat secara langsung melihat simulasi/gambar yang menyerupai fenomena sebenarnya, sehingga mahasiswa mampu memahami sekaligus (Sianturi \& Panggabean, 2019).

E-modul dikembangkan terintegrasi media berbasis Adobe Flash CS6, artinya emodul yang dikembangkan nantinya dipadukan, dihubungkan atau dikoordinasikan secara utuh dan bulat dengan media berbasis Adobe Flash CS6 serta dapat diakses atau diunduh mahasiswa pada situs e-learning Jurusan Kimia, FIMIPA Universitas Negeri Medan. Penggunaan e-modul terintegrasi media berbasis Adobe Flash CS6 diharapkan dapat menuntun mahasiswa untuk mencari pemecahan masalah secara mandiri dan hal ini akan memberikan suatu pengalaman konkret dalam menyelesaikan atau memecahkan masalah yang dihadapi mahasiswa.

\section{METODE}

Penelitian ini termasuk jenis penelitian dan pengembangan atau research and development (R\&D) dengan tujuan untuk menghasilkan produk berupa e-modul terintegrasi media berbasis Adobe Flash CS6 yang layak dan efektif dalam meningkatkan kemampuan pemecahan masalah kimia mahasiswa pada matakuliah Kimia Umum materi Termokimia. Model pengembangan yang digunakan mengacu pada model pengembangan ADDIE yang dilakukan melalui beberapa tahapan, meliputi: (a) Analisis, (b) Desain, (c) Development (d) Implementasi, dan (e) Evaluasi. Subjek dan patisipan yang terlibat dalam penelitian ini adalah praktisi atau validator ahli (dosen) dan 30 mahasiswa Program Studi Pendidikan Kimia, Universitas Negeri Medan.

Teknik dan instrumen yang digunakan pada penelitian ini, antara lain (1) wawancara yang digunakan untuk pengumpulan data ketika melakukan penelitian sebagai bahan studi pendahuluan untuk mencari permasalahan yang akan diteliti serta digunakan dalam ujicoba produk baik pada saat validasi kepada ahli maupun ujicoba produk di lapangan sebagai pertimbangan dalam perbaikan bahan ajar yang dikembangkan; (2) lembar validasi yang digunakan untuk memperoleh data tentang hasil validasi para ahli terkait e-modul terintegrasi media berbasis Adobe Flash CS6 yang dikembangkan untuk menguji kelayakan atau kevalidannya; dan (3) instrumen tes yang disusun untuk memperoleh data tentang kemampuan pemecahan masalah kimia mahasiwa. Tes disusun dalam bentuk essai sebanyak 10 soal.

Data hasil penelitian dianalisis secara bertahap untuk mengetahui kelayakan (validitas) dan keefektifan e-modul terintegrasi media berbasis Adobe Flash CS6 
yang dikembangkan. Data hasil validasi para ahli dianalisis dengan mempertimbangkan masukan, komentar, dan saran-saran dari validator. Hasil analisis tersebut dijadikan sebagai pedoman untuk merevisi e-modul dan media berbasis Adobe Flash CS6 yang dikembangkan. Validitas e-modul dan media berbasis Adobe Flash CS6 yang telah dibuat dapat dianalisis dari lembar validasi yang diisi oleh validator ahli dan hasil tanya jawab selama proses validasi. Keefektifan produk yang dikembangkan diperoleh dari hasil tes kemampuan pemecahan masalaha kimia mahasiswa. Uji keefektifan e-modul terintegrasi media berbasis Adobe Flash CS6 yang dikembangkan dianalisis dari peningkatan kemampuan pemecahan masalah kimia mahasiswa dengan uji-t menggunakan pendekatan paired sampel t-test dengan bantuan program SPSS.

\section{HASIL DAN PEMBAHASAN}

Produk yang dikembangkan berupa: (1) e-modul dan (2) media berbasis Adobe Flash CS6 pada materi termokimia. E-modul dikembangkan terintegrasi media berbasis Adobe Flash CS6, artinya e-modul yang dikembangkan dipadukan atau dikoordinasikan secara utuh dan bulat dengan media berbasis Adobe Flash CS6.

\section{Kelayakan (Validitas) Produk}

Validitas (kelayakan) e-modul dan media berbasis Adobe Flash CS6 yang dikembangkan divalidasi oleh praktisi atau validator ahli (dosen) sesuai dengan bidangnya. Hasil validasi e-modul pada aspek materi disajikan pada Tabel 1.

Tabel 1. Hasil Validasi E-Modul Pada Aspek Materi

\begin{tabular}{|c|c|c|c|c|c|}
\hline \multirow{2}{*}{ Aspek Penilaian } & \multicolumn{3}{|c|}{ Validator (Mean Skor) } & \multirow{2}{*}{$\begin{array}{l}\text { Mean } \\
\text { Total }\end{array}$} & \multirow{2}{*}{ Kriteria } \\
\hline & $\mathrm{I}$ & II & III & & \\
\hline Cakupan dan kedalaman materi & 4,50 & 4,25 & 4,50 & 4,42 & Valid \\
\hline $\begin{array}{l}\text { Ketepatan penyajian (sistematis) tidak } \\
\text { miskonsepsi pada materi }\end{array}$ & 3,50 & 4,00 & 4,00 & 3,83 & Valid \\
\hline $\begin{array}{l}\text { Kesesuaian, kejelasan animasi pada } \\
\text { materi }\end{array}$ & 3,75 & 4,00 & 4,00 & 3,92 & Valid \\
\hline Kejelasan rumus/simbol pada materi & 4,00 & 4,25 & 4,00 & 4,08 & Valid \\
\hline $\begin{array}{l}\text { Ketepatan contoh soal pada tiap kegiatan } \\
\text { belajar }\end{array}$ & 4,50 & 4,50 & 4,00 & 4,33 & Valid \\
\hline $\begin{array}{l}\text { Ketepatan jawaban soal evaluasi pada } \\
\text { tiap kegiatan belajar }\end{array}$ & 4,50 & 4,50 & 4,00 & 4,33 & Valid \\
\hline $\begin{array}{l}\text { Penilaian Kemampuan Memecahkan } \\
\text { Masalah }\end{array}$ & 4,25 & 4,00 & 4,50 & 4,25 & Valid \\
\hline \multicolumn{4}{|c|}{ Mean Total Hasil Validasi } & $\mathbf{4 , 1 7}$ & Valid \\
\hline
\end{tabular}

Tabel 1 menunjukkan hasil penilaian validator ahli materi pada e-modul diperoleh rata-rata total skor sebesar 4,17 atau dinyatakan valid. Pada aspek cakupan dan kedalaman materi diperoleh rata-rata skor 4,42 (valid); pada aspek ketepatan penyajian (sistematis) dan tidak miskonsepsi pada materi diperoleh rata-rata skor 3,83 (valid); pada aspek kesesuaian dan kejelasan animasi pada materi diperoleh rata-rata skor 3,92 (valid); pada aspek kejelasan rumus/simbol pada materi diperoleh rata-rata skor 4,08 (valid); pada aspek ketepatan contoh soal pada tiap kegiatan belajar diperoleh rata-rata skor 4,33 (valid); pada aspek ketepatan jawaban soal evaluasi pada tiap kegiatan belajar diperoleh rata-rata skor 4,33 (valid); pada aspek penilaian kemampuan pemecahan masalah diperoleh rata-rata skor 4,25 (valid). Secara keseluruhan hasil penilaian validator ahli pada aspek materi dapat disimpulkan bahwa e-modul pada materi Termokimia yang dikembangan sudah tergolong valid atau layak untuk diterapkan dalam pembelajaran Termokimia.

Hasil validasi e-modul pada aspek media secara ringkas disajikan pada Tabel 2. 
Tabel 2. Hasil Validasi E-Modul Pada Aspek Media

\begin{tabular}{|c|c|c|c|c|c|}
\hline \multirow{2}{*}{$\begin{array}{c}\text { Aspek } \\
\text { Penilaian }\end{array}$} & \multicolumn{3}{|c|}{$\begin{array}{c}\text { Validator } \\
\text { (Mean Skor) }\end{array}$} & \multirow{2}{*}{$\begin{array}{l}\text { Total } \\
\text { Mean }\end{array}$} & \multirow[t]{2}{*}{ Kriteria } \\
\hline & I & II & III & & \\
\hline $\begin{array}{l}\text { Kelayakan } \\
\text { isi }\end{array}$ & 4,42 & 4,42 & 4,25 & 4,36 & Valid \\
\hline $\begin{array}{l}\text { Kelayakan } \\
\text { penyajian }\end{array}$ & 4,40 & 4,50 & 4,40 & 4,43 & Valid \\
\hline $\begin{array}{l}\text { Kelayakan } \\
\text { bahasa }\end{array}$ & 4,11 & 4,00 & 4,11 & 4,07 & Valid \\
\hline $\begin{array}{l}\text { Kelayakan } \\
\text { kegrafikan }\end{array}$ & 4,27 & 4,18 & 4,27 & 4,24 & Valid \\
\hline $\begin{array}{l}\text { Karakteristik } \\
\text { E-Modul }\end{array}$ & 4,40 & 4,20 & 4,20 & 4,27 & Valid \\
\hline \multicolumn{4}{|c|}{ Mean Total Hasil Validasi } & 4,28 & Valid \\
\hline
\end{tabular}

Tabel 2 menunjukkan hasil penilaian validator ahli media pada e-modul diperoleh rata-rata total skor sebesar 4,28 atau dinyatakan valid. pada aspek kelayakan isi diperoleh rata-rata skor 4,36 (valid); pada aspek kelayakan penyajian diperoleh rata-rata skor 4,43 (valid); pada aspek kelayakan bahasa diperoleh rata-rata skor 4,07 (valid); pada aspek kegrafikan diperoleh rata-rata skor 4,24 (valid); dan pada aspek karakteristik emodul diperoleh rata-rata skor 4,27 (valid). Secara keseluruhan hasil penilaian validator ahli media disimpulkan bahwa e-modul materi Termokimia yang dikembangan sudah tergolong valid atau layak untuk diterapkan dalam pembelajaran Termokimia.

Lebih lanjut hasil validasi media berbasis Adobe Flash CS6, secara ringkas disajikan pada Tabel 3.

Tabel 3. Hasil Validasi Media Berbasis Adobe Flash

\begin{tabular}{|c|c|c|c|c|c|}
\hline \multirow{2}{*}{$\begin{array}{c}\text { Aspek } \\
\text { Penilaian }\end{array}$} & \multicolumn{3}{|c|}{$\begin{array}{c}\text { Validator } \\
\text { (Mean Skor) }\end{array}$} & \multirow{2}{*}{$\begin{array}{l}\text { Total } \\
\text { Mean }\end{array}$} & \multirow[t]{2}{*}{ Kriteria } \\
\hline & I & II & III & & \\
\hline $\begin{array}{l}\text { Rekayasa } \\
\text { perangkat } \\
\text { lunak }\end{array}$ & 4,00 & 4,00 & 4,10 & 4,03 & Valid \\
\hline $\begin{array}{l}\text { Tampilan } \\
\text { antar muka }\end{array}$ & 4,00 & 4,11 & 4,33 & 4,15 & Valid \\
\hline $\begin{array}{l}\text { Komunikasi } \\
\text { visual }\end{array}$ & 4,13 & 4,13 & 4,25 & 4,17 & Valid \\
\hline \multicolumn{4}{|c|}{ Mean Total Hasil Validasi } & 4,12 & Valid \\
\hline
\end{tabular}

Tabel 3 menunjukkan hasil penilaian validator ahli media pada media berbasis Adobe Flash CS6 diperoleh rata-rata total skor sebesar 4,12 atau dinyatakan valid. Pada aspek rekayasa perangkat lunak dperoleh ratarata skor 4,03 (valid); pada aspek tampilan antar muka dperoleh rata-rata skor 4,15 (valid); dan pada aspek komunikasi visual diperoleh rata-rata skor 4,17 (valid). Secara keseluruhan hasil penilaian validator ahli pada media berbasis Adobe Flash CS6 disimpulkan bahwa media berbasis Adobe Flash CS6 pada materi Termokimia yang dikembangan sudah tergolong valid atau layak untuk diterapkan dalam pembelajaran Termokimia.

\section{Keefektifan Produk}

Keefektifan produk dianalisis berdasarkan capaian hasil belajar mahasiswa sebelum dan setelah memanfaatkan e-modul terintegrasi media berbasis Adobe Flash CS6 yang dihasilkan. Tahap ini dilakukan kepada mahasiswa dan dilaksanakan dalam 3 (tiga) tahapan meliputi: (1) tahap awal yaitu pemberian tes awal (pretes) sebelum mahasiswa diberikan tindakan dengan menggunakan e-modul terintegrasi media berbasis Adobe Flash CS6 yang dihasilkan, (2) tahap kedua yaitu proses pembelajaran dimana mahasiswa belajar secara daring dengan memanfaatkan e-modul yang dapat diakses dan diunduh menggunakan laptop, komputer atau android pada situs e-learning Jurusan Kimia, serta (3) tahap ketiga yaitu pemberian tes akhir (postes) setelah pembelajaran berakhir dengan memanfaatkan e-modul terintegrasi media berbasis Adobe Flash CS6.

Keefektifan e-modul yang dikembangkan dianalisis dari peningkatan capaian hasil belajar yang diperoleh mahasiswa dalam menyelesaikan tes kemampuan pemecahan masalah pada materi Termokimia dengan menggunakan pretestposttest design. Hasil tes dianalisis dengan uji-t atau pendekatan paired sampel t-test dengan bantuan program SPSS. Hasil tes awal mahasiswa pada materi Termokimia sebelum diberikan e-modul terintegrasi media berbasis Adobe Flash CS6 (pretes) diperoleh rata-rata nilai sebesar 57,83 dan standar deviasi sebesar 2,780 dengan nilai terendah 52 dan nilai tertinggi 64 serta data memiliki sebaran yang berdistribusi normal (kolmogorov smirnov test $=0,143$ dan $p=$ $0,122)$. Setelah dilakukan tindakan melalui pembelajaran dengan menggunakan e-modul terintegrasi media berbasis Adobe Flash CS6 
dari hasil postes diperoleh rata-rata nilai kemampuan pemecahan masalah mahasiswa sebesar 80,37 dan standar deviasi sebesar 4,738 dengan nilai terendah 72 dan nilai tertinggi 89 serta data memiliki sebaran yang berdistribusi normal (kolmogorov smirnov test $=0,135$ dan $p=0,172$ ).

Keefektifan implementasi e-modul terintegrasi media berbasis Adobe Flash CS6 secara statistik dianalisis dengan uji-t atau pendekatan paired sampel t-test dengan bantuan program SPSS.

Tabel 4. Hasil Uji Keefektifan Produk (uji-t)

\begin{tabular}{|c|c|c|c|c|c|}
\hline & \multicolumn{2}{|c|}{ Paired Differences } & & \multirow[b]{2}{*}{$\mathrm{df}$} & \multirow{2}{*}{$\begin{array}{c}\text { Sig. } \\
\text { (2-tailed) }\end{array}$} \\
\hline & Mean & $\begin{array}{c}\text { Std. } \\
\text { Deviation }\end{array}$ & & & \\
\hline Pair 1 & 22,533 & 5,692 & 21,684 & 29 & 0,000 \\
\hline
\end{tabular}

Tabel 4, menunjukkan hasil uji-t dengan pendekatan paired sampel t-test diperoleh nilai thitung sebesar 21,684 dengan nilai probabilitas sebesar $0,000<0,05$. Dengan demikian disimpulkan bahwa implementasi e-modul terintegrasi media berbasis Adobe Flash CS6 yang dikembangkan pada materi Termokimia efektif dalam meningkatkan kemampuan pemecahan masalah kimia mahasiswa dengan selisih rata-rata nilai sebesar 22,533 dan standar deviasi sebesar 5,692.

\section{DISKUSI}

Hasil dari penelitian pengembangan dihasilkan produk e-modul terintegrasi media berbasis Adobe Flash CS6 yang dinyatakan valid (layak) dan efektif dalam meningkatkan kemampuan pemecahan masalah kimia mahasiswa pada materi Termokimia. Kevalidan (kelayakan) terpenuhi secara kualitatif berdasarkan penilaian para praktisi dan validator ahli yang secara keseluruhan dinyatakan dalam kategori valid. Keefektifan produk terpenuhi berdasarkan implementasi e-modul terintegrasi media berbasis Adobe Flash CS6 yang dibuktikan dari peningkatan kemampuan pemecahan masalah kimia mahasiswa dalam menyelesaikan tes pada materi Temokimia dengan rata-rata selisih atau perbedaan postes-pretes sebesar 22,533 dengan standar deviasi 5,692 serta hasil analisis $t$-test $=21,684$ dan nilai $p=0,000$ sehingga disimpulkan bahwa implementasi e-modul terintegrasi media berbasis Adobe Flash CS6 efektif dalam meningkatkan kemampuan pemecahan masalah kimia mahasiswa pada materi Termokimia.

Hasil temuan penelitian dan pengembangan ini memberi implikasi kepada para dosen dan praktisi bahwa untuk meningkatkan kemampuan pemecahan masalah kimia mahasiswa dapat dilakukan dengan mengembangkan bahan ajar inovatif salah satunya mengembangkan e-modul terintegrasi media berbasis Adobe Flash CS6 yang dapat diakses dan diunduh secara online sebagai bahan ajar atau sumber belajar mandiri bagi mahasiswa. Melalui e-modul terintegrasi media berbasis Adobe Flash CS6 ini diharapkan dapat membantu meningkatkan pemahaman, penguasaan dan kemampuan pemecahan masalah kimia mahasiswa karena melalui e-modul terintegrasi media berbasis Adobe Flash CS6 ini mahasiswa dilatih untuk berpikir kritis, kreatif, analitis terhadap informasi dan data yang ada dalam memecahkan masalah serta mahasiswa juga dapat mengulang-ulang materi kapan saja dan dimana saja.

\section{KESIMPULAN}

Penelitian dan pengembangan ini menghasilkan e-modul terintegrasi media berbasis Adobe Flash CS6 pada materi Termokimia melalui model pengembangan ADDIE. E-modul dikembangkan dan didesain secara terintegrasi dengan media berbasis Adobe Flash CS6 yang melatih mahasiswa untuk berpikir secara kritis, kreatif, analitis terhadap informasi dan data untuk memecahkan masalah kimia yang ada dalam e-modul dan media. E-modul terintegrasi media berbasis Adobe Flash CS6 yang dihasilkan juga dapat diakses mahasiswa secara online. E-modul terintegrasi media berbasis Adobe Flash CS6 yang dikembangkan telah dinyatakan valid dan terbukti efektif dalam meningkatkan kemampuan pemecahan masalah kimia mahasiswa pada materi Termokimia. 


\section{DAFTAR PUSTAKA}

Busiri, M., \& Suparji. (2015). Pengembangan Media Pembelajaran Interaktif Dengan Menggunakan Adobe Flash CS6 Pada Mata Diklat Rencana Anggaran Biaya (RAB) Di SMK Negeri 2 Surabaya. Jurnal Kajian Pendidikan Teknik Bangunan, 3(3), 81-91. https://ejournal.unesa.ac.id/index.php/ju rnal-kajianptb/article/view/12477/11516

Fauziah, I. Z., Sutrisno, \& Suwarni. (2016). Pengembangan E-Modul Berbasis Adobe Flash CS6 pada Mata Pelajaran Penataan Barang Dagang. Jurnal Pendidikan Bisnis Dan Manajemen, 2(2), 154-159. http://journal2.um.ac.id/index.php/jpbm/ article/view/1703

Gunawan, Sahidu, H., Harjono, A., \& Suranti, N. M. Y. (2017). The Effect Of Project Based Learning With Virtual Media Assistance On Student's Creativity In Physics. Jurnal Cakrawala Pendidikan, 36(2), 167-179. https://doi.org/10.21831/cp.v36i2.13514

Hidayatullah, M. S., \& Rakhmawati, L. (2016). Pengembangan Media Pembelajaran Berbasis Flip Book Maker Pada Mata Pelajaran Elektronika Dasar Di SMK Negeri 1 Sampang. Jurnal Pendidikan Teknik, 5(1), 83-88. https://ejournal.unesa.ac.id/index.php/ju rnal-pendidikan-teknikelektro/article/view/13674

Narmaditya, B. S., Wulandari, D., \& Sakarji, S. R. B. (2018). Does Problem-Based Learning Improve Critical Thinking Skills? Jurnal Cakrawala Pendidikan, 37(3), 378-388. https://doi.org/10.21831/cp.v38i3.21548

Noviar, D. (2016). Pengembangan Ensiklopedi Biologi Mobile Berbasis Android Materi Pokok Pteridophyta Dalam Rangka Implementasi Kurikulum 2013. Jurnal Cakrawala Pendidikan, 35(2), 198-207. https://doi.org/10.21831/cp.v15i2.8255
Pratiwi, P. H., Hidayah, N., \& Martiana, A. (2017). Pengembangan Modul Mata Kuliah Penilaian Pembelajaran Sosiologi Berorientasi HOTS. Jurnal Cakrawala Pendidikan, 36(2), 201-209. https://doi.org/10.21831/cp.v36i2.13123

Romadhon, M. M., \& Sutopo. (2017). Pengembangan Media Pembelajaran Teknik Pemesinan Frais Berbasis Adobe Flash CS6. Jurnal Pendidikan Vokasional Teknik Mesin, 5(2), 139-144. https://docplayer.info/63080324-

Pengembangan-media-pembelajaranteknik-pemesinan-frais-berbasis-adobeflash-cs6.html

Saselah, Y. R., Amir, M., \& Qadar, R. (2017). Pengembangan Multimedia Interaktif Berbasis Adobe Flash Cs6 Professional Pada Pembelajaran Kesetimbangan Kimia. Jurnal JKPK (Jurnal Kimia Dan Pendidikan Kimia), 2(2), 80-89. https://doi.org/DOI : 10.20961/jkpk.v2i2.11978

Sianturi, J., \& Panggabean, F. T. M. (2019). Implementasi Problem Based Learning ( PBL ) menggunakan Virtual Dan Real Lab Ditinjau dari Gaya Belajar Untuk Meningkatkan Hasil Belajar Siswa. Jurnal Inovasi Pembelajaran Kimia, 1(2), 58-63. https://doi.org/https://doi.org/10.24114/j ipk.v1i2.15460

Siregar, S. L., \& Panggabean, F. T. M. (2020). Analisis PBL Dengan DL Menggunakan Macromedia Flash Terhadap Motivasi Dan Hasil Belajar Siswa Pada Materi Laju Reaksi Di SMA Negeri 10 Medan. Jurnal Inovasi Pembelajaran Kimia, 2(1), 21-25. https://doi.org/10.24114/jipk.v2i1.17829

Suwasono. (2013). Pengembangan E-Modul Online Elektronika Analog Pada Pendidikan Jarak Jauh. Jurnal Teknologi Dan Kejuruan, 36(1), 51-62. https://doi.org/http://dx.doi.org/10.1797 7/tk.v36i1.4070 